\title{
A low molecular weight extract of bovine serum albumin stimulates rabbit blastocyst cell division and expansion in vitro
}

\author{
M. T. Kane \\ Department of Physiology, University College, Galway, Ireland
}

\begin{abstract}
Summary. Fraction $\mathrm{V}$ bovine serum albumin (BSA) was dissolved in $5 \%$ formic acid and filtered through a molecular filter with a cutoff of $M_{r} 10000$. The freeze-dried filtrate stimulated increased cell division of cultured rabbit morulae to blastocysts (up to 8-fold increase in cell number) and increased blastocyst expansion ( $>2$-fold). These results show that some samples of commercial BSA contain an embryonic growth factor of a low molecular weight.
\end{abstract}

\section{Introduction}

At present, the embryos of only a few species can be cultured during the cleavage stage and then only in media containing bovine serum albumin (BSA) or serum (reviews by Kane, 1978; Brackett, 1981). There is evidence from work with rabbit embryos that the growth-promoting effect of BSA is due to a contaminant (Kane \& Headon, 1980). It has also been shown that there is considerable variation in the growth-promoting effect of different lots of commercially available BSA (Kane, 1983). The present study examined the effect of a low molecular-weight formic-acid extract of a sample of commercial BSA with known embryonic growth-stimulating ability on the cell division and expansion of rabbit blastocysts in culture.

\section{Materials and Methods}

Embryos. Embryos at the early morula stage were collected from the oviducts of superovulated New Zealand White does 44-48 h after LH injection as described previously (Kane, 1983). Embryos were placed in culture in $0.5 \mathrm{ml}$ droplets of culture medium under paraffin liquid (Merck, Darmstadt, West Germany, Art. 7162) in tissue culture dishes. Culture dishes were maintained at $38^{\circ} \mathrm{C}$ under a gas phase of $5 \% \mathrm{CO}_{2}$ in air. At the end of 4 days culture the numbers of blastocysts and hatched blastocysts were recorded and blastocyst diameters were measured with an eyepiece micrometer. Blastocysts were then stained with aceto-orcein- $\mathrm{HCl}$ (Grayson, 1978; Kane, 1983) and cell numbers counted under high power with the aid of an eyepiece micrometer grid.

Culture medium. The composition of the basic culture medium to which additions were made was $0.5 \%$ defatted charcoal-treated BSA (Sigma, Poole England, Cat. no. A 7511 ), $108 \mathrm{~mm}-\mathrm{NaCl}$, $4.78 \mathrm{~mm}-\mathrm{KCl}, 1.71-\mathrm{mM}^{-\mathrm{CaCl}_{2}} .2 \mathrm{H}_{2} \mathrm{O}, 1.19 \mathrm{~mm}-\mathrm{KH}_{2} \mathrm{PO}_{4}, 1.19 \mathrm{~mm}-\mathrm{MgSO}_{4} .7 \mathrm{H}_{2} \mathrm{O}, 25 \mathrm{~mm}-$ $\mathrm{NaHCO}_{3}, 0.5 \mathrm{~mm}$-sodium pyruvate, $1 \mathrm{mM}$-glucose, 100 units penicillin $\mathrm{G} / \mathrm{ml}, 50 \mu \mathrm{g}$ streptomycin sulphate $/ \mathrm{ml}$ and the amino acids, vitamins and trace elements of Ham's F10 medium (Ham, 1963; Kane \& Foote, 1970). The charcoal-treated BSA was added to the basic medium (1) as a type of BSA from which most small molecules have been removed, (2) because it is possible that rabbit blastocyst development requires protein in the medium for ${ }^{\circ}$ physicochemical reasons, 2 eand 3 (3) 
because it has been suggested that BSA can protect embryos against toxic substances and preliminary work showed that high levels of the low molecular weight extract of BSA were toxic to the embryos.

Preparation of low molecular-weight extract of BSA. The BSA used was Fraction V from Sigma (Cat. no. A 4503, lot no. 120F-0089); $3 \mathrm{~g}$ were dissolved in $60 \mathrm{ml} 5 \%$ formic acid solution and then filtered through a membrane with a cutoff of $M_{r} 10000$ (Millipore Pellicon type PT) using an Amicon Model 52 stirred cell and the filtrate was collected. The retentate $(\sim 10 \mathrm{ml})$ from the first filtration was made up to $60 \mathrm{ml}$ with $5 \%$ formic acid and refiltered. The refiltrate was collected and pooled with the material from the first filtration and then freeze-dried. The yield of freeze-dried molecular weight extract was about $10 \mathrm{mg} / \mathrm{g}$ Fraction V BSA. Extraction with $5 \%$ formic acid has been used to extract somatomedins from plasma proteins (Liberti, 1975).

Experimental design. The experiment was a randomized complete block design with 6 treatments. The treatments were basic medium alone and with $0.04,0.2$ and $1.0 \mathrm{mg}$ low molecularweight extract/ml and with 1 and $5 \mathrm{mg}$ unextracted Fraction V BSA $/ \mathrm{ml}$. Each block of the experiment consisted of the morulae collected on one day divided approximately equally amongst the 6 treatments. The experiment was replicated 5 times. The blastocyst cell counts and blastocyst diameters were analysed by analysis of variance.

\section{Results}

High proportions of the embryos formed blastocysts in all treatments (Table 1) and there was no significant effect of treatment on blastocyst formation. This reflects the fact that embryos collected at the morula stage are within about 1 day of blastocyst formation and so require only a limited degree of growth to start blastulation.

However, blastocyst expansion and cell division were extremely limited in the control treatment without any additive. After a short initial period of expansion most blastocysts rapidly shrank to their original unexpanded size. There were significant linear and quadratic effects $(P<0.001)$ of the low molecular weight material on blastocyst cell number and blastocyst diameter. The addition of $0.2 \mathrm{mg}$ extract of BSA $/ \mathrm{ml}$ stimulated a very marked increase in the mean blastocyst cell number and the mean blastocyst diameter and this growth-promoting effect was comparable to that found after treatment with $5 \mathrm{mg}$ unextracted BSA/ml (Table 1; Pl. 1, Figs 1-4). The highest level of extract $(1 \mathrm{mg} / \mathrm{ml})$ did not give an improved response over that of $0.2 \mathrm{mg} / \mathrm{ml}$ and this is reflected in the significant quadratic effect. This is most probably due to a toxic effect of the extracted material. This was borne out by the fact that in a separate experiment $5 \mathrm{mg} \mathrm{extract} / \mathrm{ml}$ in the presence of $0.5 \%$ charcoal-treated BSA killed 11/11 embryos at the early blastocyst stage.

\section{PLATE 1}

Photomicrographs of an unstained rabbit morula before culture (Fig. 1) and 3 stained blastocysts after culture for 4 days (Figs 2-4).

Fig. 1. Unstained morula collected about $44 \mathrm{~h}$ after insemination and an ovulatory injection of LH. The inner envelope, the zona pellucida (laid down in the ovary) and the outer envelope, the mucin coat (laid down in the oviduct) are clearly visible. These envelopes are absent in Figs $2-4$ due to zona shedding (hatching) by the blastocyst in culture and/or destruction of the envelopes by the fixing and staining procedure. $\times 290$.

Fig. 2. Blastocyst after culture in basic medium without any additive. $\times 290$.

Fig. 3. Blastocyst in basic medium plus $0.2 \mathrm{mg}$ low molecular weight extract of $\mathrm{BSA} / \mathrm{ml}$. $\times 1456$.

Fig. 4. Blastocyst in basic medium plus $5 \mathrm{mg}$ unextracted $\mathrm{BSA} / \mathrm{ml} . \times 145 \%$ 
PLATE 1
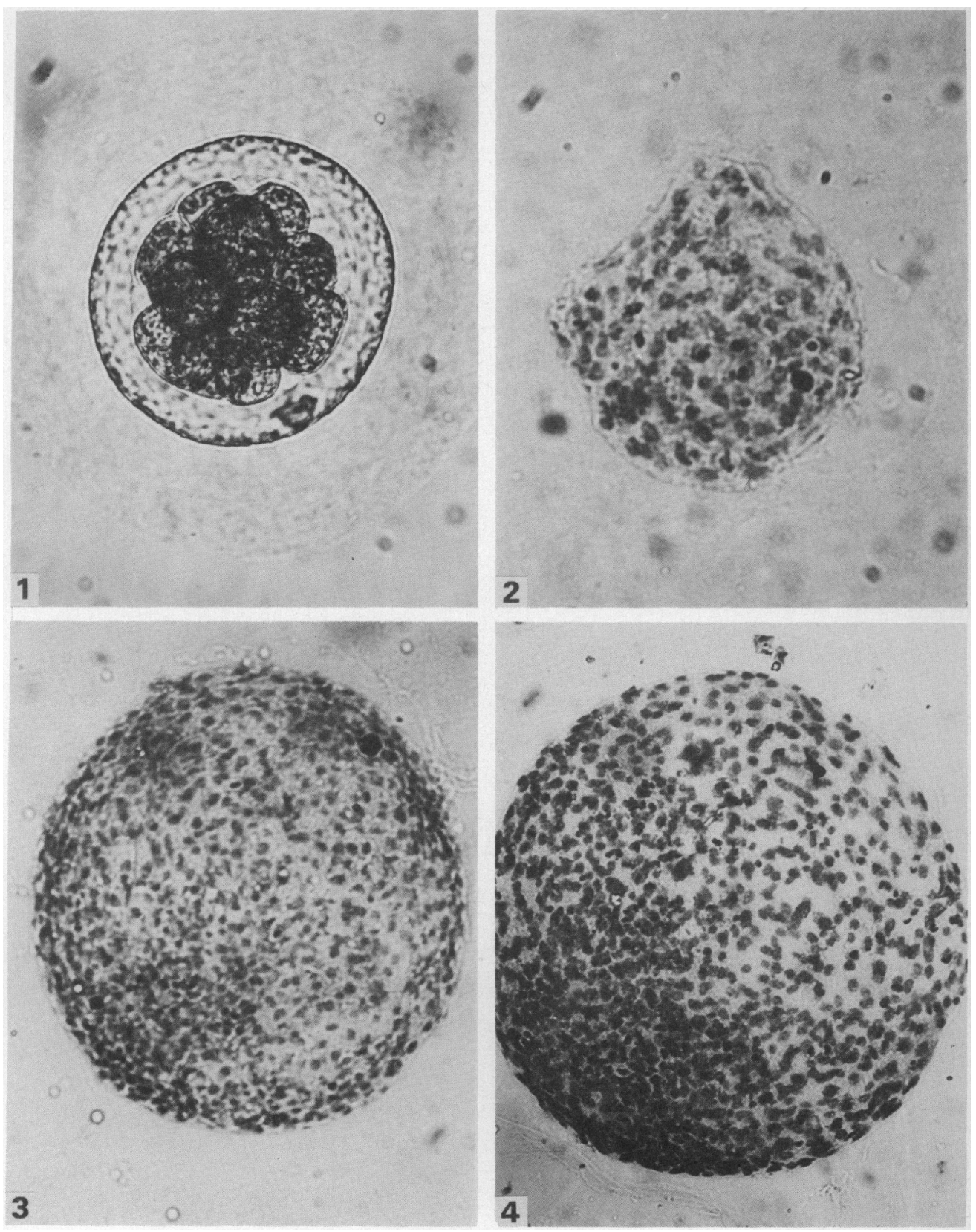
Table 1. Effect of low molecular-weight extract of BSA on rabbit blastocyst formation, expansion and cell division

\begin{tabular}{|c|c|c|c|c|c|c|}
\hline & \multirow{2}{*}{$\begin{array}{c}\text { Basic } \\
\text { medium } \\
\text { alone }\end{array}$} & \multicolumn{3}{|c|}{$\begin{array}{l}\text { Basic medium }+ \text { low } \\
\text { molecular-weight extract }(\mathrm{mg} / \mathrm{ml})\end{array}$} & \multicolumn{2}{|c|}{$\begin{array}{c}\text { Basic medium }+ \\
\text { unextracted BSA }(\mathrm{mg} / \mathrm{ml})\end{array}$} \\
\hline & & 0.04 & $0 \cdot 2$ & $1 \cdot 0$ & 1 & 5 \\
\hline No. of embryos & 51 & 50 & 48 & 49 & 56 & 57 \\
\hline$\%$ blastocysts & 100 & 100 & 98 & 98 & 96 & 96 \\
\hline$\%$ hatched blastocysts & 0 & 0 & 6 & 10 & 0 & 19 \\
\hline $\begin{array}{l}\text { Embryo cell count } \\
(\text { mean } \pm \text { s.e.m. })\end{array}$ & $99 \pm 7$ & $210 \pm 29$ & $807 \pm 65$ & $806 \pm 55$ & $316 \pm 55$ & $1128 \pm 122$ \\
\hline $\begin{array}{l}\text { Embryo diam. } \\
\quad(\mu \mathrm{m}, \text { mean } \pm \text { s.e.m. })\end{array}$ & $155 \pm 7$ & $191 \pm 9$ & $349 \pm 13$ & $328 \pm 14$ & $214 \pm 12$ & $457 \pm 27$ \\
\hline
\end{tabular}

A low percentage of blastocysts hatched completely from the zona pellucida when treated with extract at levels of 0.2 and $1 \mathrm{mg}$ but a higher percentage hatched from the zona in $5 \mathrm{mg}$ unextracted $\mathrm{BSA} / \mathrm{ml}$.

\section{Discussion}

The finding that a low molecular-weight contaminant of BSA has such a dramatic effect on cell division in rabbit blastocysts is particularly interesting because of the numerous reports that high levels of BSA stimulate blastocyst growth in a number of other species (mouse: Wales \& Whittingham, 1973; sheep: Lindner, Dickey \& Hill, 1983; pig: Wright, 1977; Lindner \& Wright, 1978). The isolation and identification of the factor stimulating growth of rabbit blastocysts may have relevance to embryonic growth in these species. I am now purifying the low molecular weight extract by column chromatography.

Substitution of the standard culture medium by MCDB 104, an extremely complex tissue culture medium (McKeehan \& Ham, 1976) with an extensive range of cofactors, did not give the same stimulatory effect as the low molecular weight extract (M. T. Kane, unpublished data). This indicates that the BSA factor is probably not one of the usual forms of a vitamin or other growth factor.

If one assumes that the level of $0.2 \mathrm{mg}$ extract $/ \mathrm{ml}$ medium is almost equivalent to $5 \mathrm{mg}$ Fraction $\mathrm{V} \mathrm{BSA} / \mathrm{ml}$ containing $0.05 \mathrm{mg}$ extract then it is clear that either extraction is incomplete or else the extraction process is destroying some activity. Later work with an Amicon hollow-fibre cartridge instead of the stirred cell has increased the extraction rate from the $10 \mathrm{mg} / \mathrm{g}$ BSA found with the stirred cell to $14 \mathrm{mg} / \mathrm{g}$ and has also decreased the optimum level of the extracted material nearer to $0.04 \mathrm{mg} / \mathrm{ml}$ indicating an increased activity (M. T. Kane, unpublished data).

The results show that as well as containing a growth-promoting factor the extract contains toxic substances. While it is quite possible that there are toxic substances normally bound to BSA it is also probable that the extraction procedure itself using $5 \%$ formic acid produces toxic materials either by alteration of existing compounds on the BSA or by the leaving behind of residual impurities present in the formic acid. It is also possible that the growth-stimulating factor itself is toxic at levels greater than the optimum. The fact that there is a low molecular-weight growthpromoting factor present as a contaminant in some samples of BSA helps to explain some of the variability associated with the use of BSA as a source of macromolecules for embryo culture (Kane, 1983).

I thank the National Board for Science and Technology for grant funding and Mrs Patricia Commins for technical assistance. 


\section{References}

Brackett, B.G. (1981) In vitro culture of the zygote and embryo. In Fertilization and Embryonic Development in Vitro, pp. 61-79. Eds L. Mastroianni, Jr \& J. D. Biggers. Plenum Press, New York.

Grayson, K. (1978) An improved method for staining mammalian oocytes. Stain Technol. 53, 115-116.

Ham, R.G. (1963) An improved nutrient solution for diploid hamster and human cell lines. Expl Cell Res. 29, 515-526.

Kane, M.T. (1978) Culture of mammalian ova. In Control of Reproduction in the Cow, pp. 383-387. Ed. J. M. Sreenan. Martinus Nijhoff, The Hague.

Kane, M.T. (1983) Variability in different lots of commercial bovine serum albumin affects cell multiplication and hatching of rabbit blastocysts in culture. J. Reprod. Fert. 69, 555-558.

Kane, M.T. \& Foote, R.H. (1970) Culture of two- and four-cell rabbit embryos to the expanding blastocyst stage. Proc. Soc. exp. Biol. Med. 133, 921-925.

Kane, M.T. \& Headon, D.R. (1980) The role of commercial bovine serum albumin preparations in the culture of one-cell rabbit embryos to blastocysts. J. Reprod. Fert. 60, 469-475.
Liberti, J.P. (1975) Purification of bovine somatomedin. Biochem. Biophys. Res. Commun. 67, 1221-1233.

Lindner, G.M. \& Wright, R.W., Jr (1978) Morphological and quantitative aspects of the development of swine embryos in vitro. J. Anim. Sci. 46, 711-718.

Lindner, G.M., Dickey, J.F. \& Hill, J.R., Jr (1983) Effect of bovine serum albumin concentration on the development of ovine embryos in vitro. J. Anim. Sci. 57, 466-472.

McKeehan, W.L. \& Ham, R.G. (1976) Stimulation of clonal growth of normal fibroblasts with substrata coated with basic polymers. J. Cell Biol. 71, 727-734.

Wales, R.G. \& Whittingham, D.G. (1973) Development of eight-cell mouse embryos in substrate-free medium. J. Reprod. Fert. 32, 316-317.

Wright, R.W., Jr (1977) Successful culture in vitro of swine embryos to the blastocyst stage. J. Anim. Sci. 44, 854-858.

Received 5 April 1984 